\title{
Lippia alba essential oil promotes survival of silver catfish (Rhamdia quelen) infected with Aeromonas sp.
}

\author{
FERNANDO J. SUTILI ${ }^{1}$, MAURO A. CUNHA ${ }^{1}$, ROSANGELA E. ZIECH ${ }^{2}$, CARINA C. KREWER ${ }^{2}$, \\ CARLA C. ZEPPENFELD ${ }^{1}$, CLARISSA G. HELDWEIN ${ }^{3}$, LETICIA T. GRESSLER ${ }^{2}$, \\ BERTA M. HEINZMANN ${ }^{3}$, AGUEDA C. VARGAS ${ }^{2}$ and BERNARDO BALDISSEROTTO ${ }^{1}$ \\ ${ }^{1}$ Universidade Federal de Santa Maria, Departamento de Fisiologia e Farmacologia, Bairro Camobi, \\ Av. Roraima, 1000, 97105-900 Santa Maria, RS, Brasil \\ ${ }^{2}$ Universidade Federal de Santa Maria, Departamento de Medicina Veterinária Preventiva, Bairro Camobi, \\ Av. Roraima, 1000, 97105-900 Santa Maria, RS, Brasil \\ ${ }^{3}$ Universidade Federal de Santa Maria, Departamento de Farmácia Industrial, Bairro Camobi, \\ Av. Roraima, 1000, 97105-900 Santa Maria, RS, Brasil
}

Manuscript received on November 5, 2013; accepted for publication on April 3, 2014

\begin{abstract}
In vitro and in vivo activity of the Lippia alba essential oil (EO) against Aeromonas sp. was evaluated. In the in vitro assay the minimum inhibitory concentration (MIC) and a minimum bactericidal concentration (MBC) of EO for Aeromonas cells were determined using the microdilution method. Twenty five strains of Aeromonas sp. isolated from infected fish obtained from local fish farms were used. MIC and MBC values were 2862 and 5998 $\mu \mathrm{g} \mathrm{mL}{ }^{-1}$ for $L$. alba $\mathrm{EO}$ and 0.5 and $1.2 \mu \mathrm{g} \mathrm{mL}^{-1}$ for gentamicin, respectively. In the in vivo assay silver catfish juveniles (Rhamdia quelen) $(7.50 \pm 1.85 \mathrm{~g}$ and $10.0 \pm 1.0 \mathrm{~cm})$ with typical injuries associated to Aeromonas infection were divided into four treatments (in triplicate $\mathrm{n}=10$ ): untreated fish (negative control), $10 \mathrm{mg} \mathrm{L}^{-1}$ of gentamicin, and 20 or $50 \mu \mathrm{LL}^{-1}$ of EO. Fish were maintained in aerated $20 \mathrm{~L}$ plastic boxes. After 10 days survival of silver catfish infected with Aermonas sp. and treated with essential oil $\left(50 \mu \mathrm{L} \mathrm{L}^{-1}\right)$ was greater than $90 \%$.
\end{abstract}

Key words: antibacterial activity, essential oils, fish, gentamicin.

\section{INTRODUCTION}

Various drugs have been used for treatment or prevention in aquaculture diseases. The abuse of these drugs is associated with several problems, such as the presence of illegal residues in meat and transmission of resistant bacteria to the environment, animals and man, a potential risk to public health (Schmidt et al. 2000). As an alternative to conventional drugs, medicinal plants have been widely used in veterinary and human medicine and nowadays also have a

Correspondence to: Mauro Alves Cunha

E-mail: cunha.mauroalves@gmail.com significant role in aquaculture as prophylactic and therapeutic agents against fish pathogens, presenting antiviral, antibacterial, antifungal and antiparasitic potential (Citarasu 2010). Essential oils and extracts from plants could provide a viable alternative to conventional drugs minimizing the economic losses resulting from infections. These natural products contain a rich blend of highly functional molecules some of which are beneficial but others which are not, presenting toxicity. However, in the environment, this toxicity is very low compared with those of synthetic pesticides or drugs (Park et al. 2011). 
Outbreaks of bacteria of the genus Aeromonas in fish are associated with changes in environmental conditions and/or stress factors like parasitic infections (Barcellos et al. 2008). Usually considered a secondary pathogen, bacteria of Aeromonas genus can also act as a primary pathogen in some environments, causing high mortality in fish farms (Nielsen et al. 2001).

The aim of the present study was to find a natural alternative to prevent/treat infections caused by bacteria of Aeromonas genus in Rhamdia quelen, a native species suitable for fish culture in southern Brazil. Lippia alba was chosen because of its antimicrobial and anti-inflammatory potential (Pascual et al. 2001, Glamočlija et al. 2011).

\section{MATERIALS AND METHODS}

ESSENTIAL OIL

Lippia alba (Mill.) N. E. Brown was cultivated in São Luiz Gonzaga, Rio Grande do Sul, Brazil. The plant material was identified by botanist Dr. Gilberto Dolejal Zanetti, Departamento de Farmácia Industrial, Universidade Federal de Santa Maria (UFSM), and a voucher specimen (SMDB N ${ }^{\circ} .10050$ ) was deposited in the UFSM herbarium. Lippia alba essential oil (EO) was extracted from the fresh leaves of the plant by hydrodistillation for 2 hours using a Clevenger type apparatus (European Pharmacopoeia 2007). The EO samples were stored at $-4^{\circ} \mathrm{C}$ in amber glass bottles and $\mathrm{EO}$ analysis was performed by gas chromatography-mass spectrometry (GC/MS). The major components were linalool and 1,8-cineol (Table I) (Barros et al. 2009).

IN VITRO ASSAY

Minimum inhibitory concentration (MIC) and minimum bactericidal concentration (MBC) of EO for Aeromonas cells were determined using the microdilution method in accordance with the guidelines of the Clinical and Laboratory Standards Institute, document M31-A3 (CLSI 2008). The EO was previously diluted in ethanol to obtain the initial concentration of $176100 \mu \mathrm{g} \mathrm{mL} \mathrm{m}^{-1}$ and twofold dilutions were performed. Twenty five isolates of Aeromonas sp. from infected fish obtained from local fish farms were used. Reference samples (Aeromonas hydrophila ATCC 7966, Staphylococcus aureus ATCC 25923 and Escherichia coli ATCC 25922) were used as quality control. The inoculum was prepared in saline solution from cultures grown in Mueller-Hinton agar $\left(1 \times 10^{8} \mathrm{CFU} \mathrm{mL}^{-1} ; 0.14 \mathrm{OD}\right.$ $600 \mathrm{~nm})$ and $10 \mu \mathrm{L}\left(1 \times 10^{5} \mathrm{CFU}\right)$ was added to each microplate well containing EO. The microplates were incubated at $35^{\circ} \mathrm{C}$ for 24 hours under aerobic conditions. The positive control was performed with gentamicin antibiotic.

IN VIVO ASSAY

Silver catfish juveniles $(7.50 \pm 1.85 \mathrm{~g}$ and 10.0 $\pm 1.0 \mathrm{~cm}$ ) were obtained from a fish culture and transported to the laboratory where they were kept in continuously aerated $250 \mathrm{~L}$ tanks $\left(23 \pm 1{ }^{\circ} \mathrm{C}, \mathrm{pH}\right.$ 6.6 - 7.0, dissolved oxygen levels $5.8-7.2 \mathrm{mg} \mathrm{L}^{-1}$ ). Fish arrived at the laboratory with typical injuries associated to Aeromonas infection. Bacterial infection of fish by Aeromonas was confirmed by morphological and biochemical characteristics analyzed in accordance to Quinn (1994).

To evaluate silver catfish survival, juveniles were divided into four treatments (in triplicate $\mathrm{n}=10$ ): untreated fish (negative control); $10 \mathrm{mg}$ $\mathrm{L}^{-1}$ of gentamicin (Belem-Costa and Cyrino 2006), and two EO concentrations (20 and $50 \mu \mathrm{L}$ $\left.\mathrm{L}^{-1}\right)$ equivalent to 16 and $40 \mathrm{mg} \mathrm{L}^{-1}$, respectively, because the density of this EO is approximately $0.80 \mathrm{~g} \mathrm{~mL}^{-1}$. Fish were maintained for 10 days in aerated $20 \mathrm{~L}$ polyethylene boxes. These concentrations were chosen because L. alba EO in concentrations above $100 \mu \mathrm{L} \mathrm{L}^{-1}$ induce deep anesthesia in $R$. quelen (Cunha et al. 2010). Fish were fed once a day to satiety, and $30 \mathrm{~min}$ later feces and food remains were removed by siphoning. To avoid dilution of the EO the water volume withdrawn during each siphoning (250 
$\mathrm{mL}$ ) was not replaced until eighth day, when all water was replaced. The methodology of this experiment was approved by the Ethical and Animal Welfare Committee of the Universidade Federal de Santa Maria (Process N. 046/2010).

Dissolved oxygen and temperature were measured with YSI oxygen meter. The water $\mathrm{pH}$ was verified with a DMPH-2 $\mathrm{pH}$ meter. Total ammonia nitrogen (TAN) levels were determined by Nessler method in accordance to Eaton et al. (2005). Unionized ammonia $\left(\mathrm{NH}_{3}\right)$ levels were calculated as per Colt (2002).

Fish survival was compared by Kaplan-Meier survival analysis with Logrank Test (SPSS 18 Software). The minimum significance level was set at $P<0.05$.

\section{RESULTS AND DISCUSSION}

In the in vitro test $\mathrm{MIC}$ and $\mathrm{MBC}$ values were 2862 and $5998 \mu \mathrm{g} \mathrm{mL}^{-1}$ for L. alba $\mathrm{EO}$ and 0.5 and $1.2 \mu \mathrm{g} \mathrm{mL}^{-1}$ for gentamicin, respectively (Table II). At the beginning of the experiment $85 \%$ of the fish from each treatment had signs of infection, including ulcerated fins and tissue loss between fin rays with haemorrhage, ulcerative dermal lesions, abnormal coloration (darkening) and lesions in the genital pore and anus. In the control group, these signs and lesions remained and gradually increased until all the fish died. Between the fourth and sixth day of treatment, $65 \%$ of fish treated with $50 \mu \mathrm{L} \mathrm{L}^{-1}$ EO did not show evidence of any lesions. Fish treated with 20 $\mu \mathrm{L} \mathrm{L}^{-1} \mathrm{EO}$ or gentamicin only showed the same improvement between the sixth and eighth days of the experiment. The mortality in the control group was $100 \%$ at the end of experiment. In groups treated with gentamicin $\left(10 \mathrm{mg} \mathrm{L}^{-1}\right)$ and $20 \mu \mathrm{L} \mathrm{L}^{-1}$ of EO survival was greater than $80 \%$. In the group treated with $50 \mu \mathrm{L} \mathrm{L}^{-1}$ of EO survival was greater than $90 \%$ (Figure 1). The survival was not significantly different between groups treated with EO and gentamicin.

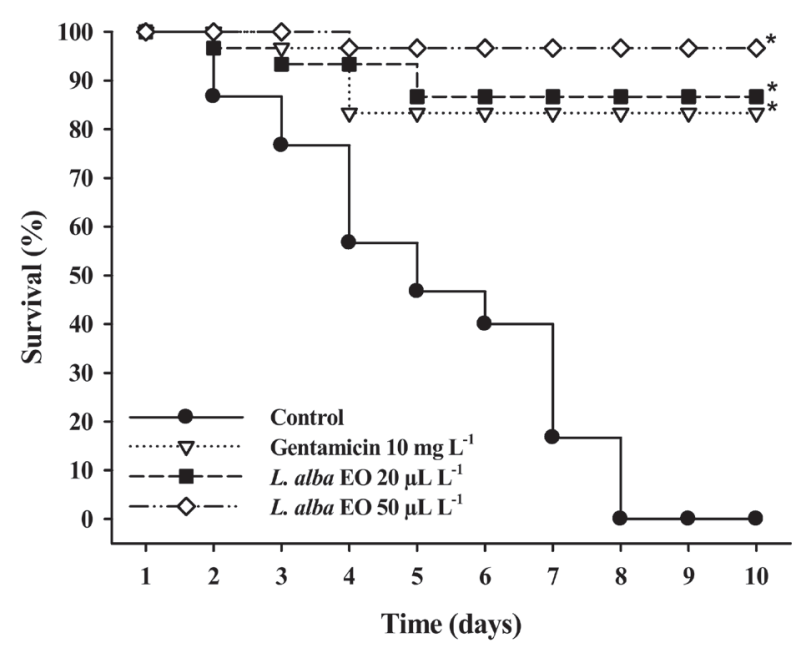

Figure 1 - Survival of juvenile silver catfish infected with Aeromonas sp. and treated with L. alba EO. (*) indicates significant difference relative to negative control. KaplanMeier survival analysis with Logrank test $(P<0.05)$.

The active compounds of herbs possess characteristics that could be useful in fish and shrimp culture; various herbs can stimulate growth and appetite, increase immune system responses, and have broad spectrum antimicrobial activity (Friedman et al. 2002). Different species of Lippia have been used against Gram-positive and Gram-negative bacteria (Pascual et al. 2001). According to Ríos and Recio (2005) only extracts or essential oils that kill or inhibit bacterial growth at concentrations below $100 \mu \mathrm{g} \mathrm{mL} \mathrm{m}^{-1}$ should be considered active. Based on their statement, L. alba EO would not be interesting for future research because a MIC of $2862 \mu \mathrm{g} \mathrm{mL} L^{-1}$ was observed. However, the in vivo results of the test conducted with silver catfish infected with Aeromonas sp. and treated with this EO demonstrated higher survival compared with control group.

Plasma cortisol level is widely used as a general indicator of stressful situations in vertebrates and particularly in fish (Pickering and Pottinger 1989) and high plasma cortisol levels cause secondary immunosuppression (Wedemeyer and Mcleay 1981). The observed effect of L. alba EO may 
be due to its effects on the fish' immune system because this EO prevented the cortisol rise in $R$. quelen submitted to acute stress (Cunha et al. 2010). Glycyrrhizin (Jang et al. 1995), aloe (Kim et al. 1999), and azadirachtin (Logambal and Michael 2001) enhance innate immunity in fishes. Oral administration of Quillaja saponin increased leucocyte migration in yellowtail Seriola quinqueradiata (Ninomiya et al. 1995). The use of diets supplemented with the medicinal plants Cynodon dactylon, Aegle marmelos, Withania somnifera, and Zingiber officinale increased non-specific immune responses and bacterial resistance against Vibrio alginolyticus, Vibrio parahaemolyticus, Vibrio mimicus, Vibrio campbelli, Vibrio vulnificus, Vibrio harveyi, and Photobacterium damselae, and these compounds lead to lower mortality in tilapia (Oreochromis mossambicus) compared with control fish (Immanuel et al. 2009). The exact mechanism of action of herbal extracts on the fish immune system is still unclear (Harikrishnan et al. 2011).

The pathogenesis of Aeromonas genus is multifactorial and depends upon the secretion of numerous extracellular virulence factors ( $\mathrm{Yu}$ et al. 2005). Research shows that subinibitory concentrations of EOs from plants decrease or inhibit the production of certain virulence factors in bacteria. Essential oils of plants can inhibit biofilm formation or the production of exotoxins such as haemolysins that cause erythrocytes hemolysis thus reducing the bacteria pathogenicity (Smith-Palmer et al. 2004, Cândido et al. 2010, Millezi et al. 2013). Thymus vulgaris EO significantly reduced biofilm formation in Aeromonas hydrophila. The major compound in T. vulgaris EO was 1,8-cineol (Millezi et al. 2013) which is also found in L. alba EO. Linalool-rich EO from L. alba inhibited the activity of proteases and keratinases secreted from dermatophytes, which are important virulence factors in this fungus (Costa et al. 2014).
Additionally, it is desirable that antibiotic use in fish cultures be reduced and replaced by natural medicines to prevent the emergence of bacterial resistance in aquatic animals and its environment. In Brazil, antibiotics, such as oxytetracycline, are widely used in fish farms to prophylactically treat bacterial infections and as a growth promoter. Despite its widespread use, there is no regulation on this drug class in fish (Rigos and Troisi 2005).

Our results demonstrate that L. alba EO has weak in vitro activity against Aeromonas sp. However, the EO added to water at lower concentrations than the anesthetic concentration, promotes survival in fish infected with this bacterial genus. Further studies should be conducted to verify this activity against other pathogenic bacteria of interest in aquaculture and to confirm immune response involvement or its potential as a virulence factors inhibitor.

\section{ACKNOWLEDGMENTS}

The authors acknowledge support from $\mathrm{CNPq}$ (Conselho Nacional de Desenvolvimento Científico e Tecnológico, process 470964/2009-0 and Fundação de Amparo à Pesquisa do Estado do Rio Grande do Sul- FAPERGS-PRONEX process 10/0016-8). B. Baldisserotto received a CNPq (Conselho Nacional de Desenvolvimento Científico e Tecnológico, Brazil) research grant, and M.A. Cunha received a CAPES (Coordenação de Aperfeiçoamento de Pessoal de Nível Superior) postdoctoral grant.

\section{RESUMO}

Avaliou-se a atividade in vitro e in vivo do óleo essencial (OE) de Lippia alba contra Aeromonas sp. No ensaio in vitro foram determinadas a concentração inibitória mínima (CIM) e a concentração bactericida mínima (CBM) do OE contra Aeromonas utilizando o método de microdiluição. Foram utilizadas 25 isolados de Aeromonas sp. isoladas de peixes infectados obtidos de pisciculturas locais. Os valores de CIM e CBM foram 2862 e $5998 \mu \mathrm{g} \mathrm{mL}^{-1}$ para o OE de L. alba e 
0.5 e $1.2 \mu \mathrm{g} \mathrm{mL}^{-1}$ para gentamicina, respectivamente. No ensaio in vivo juvenis de jundiá (Rhamdia quelen) $(7.50 \pm 1.85 \mathrm{~g}$ e $10.0 \pm 1.0 \mathrm{~cm})$ com típicas lesões associadas à infecção por Aeromonas foram divididos e 4 tratamentos (em triplicata $n=10$ ): peixes não tratados (controle negativo), gentamicina $10 \mathrm{mg} \mathrm{L}^{-1}$, e 20 ou 50 $\mu \mathrm{L} \mathrm{L}^{-1}$ do OE. Os peixes foram mantidos em caixas plásticas aeradas de $20 \mathrm{~L}$. Após 10 dias a sobrevivência de jundiás infectados com Aermonas sp. e tratados com o $\mathrm{OE}\left(50 \mu \mathrm{L} \mathrm{L}^{-1}\right)$ foi superior a $90 \%$.

Palavras-chave: atividade antibacteriana, gentamicina, óleos essenciais, peixes.

\section{REFERENCES}

Barcellos LJG, Kreutz LC, Rodrigues LB, Dos Santos LR, DA MotTA AC, RitTer F, Bedin AC AND DA Silva LB. 2008. Aeromonas hydrophila in Rhamdia quelen: macroscopic and microscopic aspect of the lesions and antibiotic resistence profiles. Bol Inst Pesca 34(3): 355-363.

BArRos FMC, ZAMBARdA EO, HEINZMANN BM AND MALLMANN CA. 2009. Variabilidade sazonal e biossíntese de terpenóides presentes no óleo essencial de Lippia alba (Mill.) N. E. Brown (Verbenaceae). Quim Nova 32(4): 861-867.

BeLEM-Costa A AND CYRINo JEP. 2006. Antibiotic resistance of Aeromonas hydrophila isolated from Piaractus mesopotamicus (Holmberg, 1887) and Oreochromis niloticus (Linnaeus, 1758). Sci Agric 63(3): 281-284.

CÂNDIDO SC, Portella CSA, LARANJEIRA BJ, DA Silva SS, Arriaga AMC, SANTIAGO GMP, GOMES GA, Almeida PC AND CARVAlHo CBM. 2010. Effects of Myrcia ovata Cambess. essential oil on planktonic growth of gastrointestinal microorganisms and biofilm formation of Enterococcus faecalis. Braz J Microbiol 41(3): 621-626.

CitARASU T. 2010. Herbal biomedicines: a new opportunity for aquaculture industry. Aquacult Int 18: 403-414.

CLSI - CLINICAL LABORATORY STANDARDS INSTITUTE. 2008. Antimicrobial disk and dilution susceptibility tests for bacteria isolated from animals: approved standard. $3^{\text {rd }} \mathrm{Ed}$. CLSI document M31-A3. Wayne, PA, USA.

COLT J. 2002. List of spreadsheets prepared as a complement. Available at: http://www.fisheries.org/afs/hatchery.html In: Wedemeyer GA (Ed), Fish hatchery management. Second Ed. American Fisheries Society.

Costa DC, Vermelho AB, Almeida CA, Dias EP, Cedrola SM, Arrigoni-Blank MD, Blank AF, Alviano CS AND ALVIANO DS. 2014. Inhibitory effect of linaloolrich essential oil from Lippia alba on the peptidase and keratinase activities of dermatophytes. J Enzyme Inhib Med Chem 29: 12-17.
CUnHa MA, Barros CMF, Garcia LO, VeECK APL, HEINZMANN BM, LORO VL, EMANUELli T AND BALDisserotTo B. 2010. Essential oil of Lippia alba: A new anesthetic for silver catfish, Rhamdia quelen. Aquaculture 306: 403-406.

EAton AD, Clesceri LS, Rice EW, GReEnBerg AE AND FRANSON MAH. 2005. Standard Methods for the Examination of Water and Wastewater ( $21^{\text {st }}$ edition). American Public Health Association, Washington DC.

European Pharmacopoeia. 2007. Strassbourg, European Directorate for the Quality of Medicines, $6^{\text {th }}$ ed.

Friedman M, HENIKA PR AND MANDRELL RE. 2002. Bactericidal activities of plant essential oils and some of their isolated constituents against Campylobacter jejuni, Escherichia coli, Listeria monocytogenes and Salmonella enterica. J Food Prot 65(10): 1545-1560.

Glamočlija J, SOKović M, TeŠEcić V, Linde GA AND COLAUTO NB. 2011. Chemical characterization of Lippia alba essential oil: an alternative to control green molds. Braz J Microbiol 42(4): 1537-1546.

HARIKRISHNAN R, BALASUNDARAM CAND HEO M. 2011. Impact of plant products on innate and adaptive immune system of cultured finfish and shellfish. Aquaculture 317: 1-15.

IMMANUEL G, UMA RP, IYAPPARAJ P, CitARASU T, PUNITHA Peter SM, Michael Babu M and Palavesam A. 2009. Dietary medicinal plant extracts improve growth, immune activity and survival of tilapia Oreochromis mossambicus. J Fish Biol 74: 1462-1475.

JANG SI, MARSDEN MJ, KIM YG, ChOI MS AND SECOMBES CJ. 1995. The effect of glycyrrhizin on rainbow trout, Oncorhynchus mykiss (Walbaun), leucocyte responses. J Fish Dis 18: 307-315.

KIM KH, HwANG YJ AND BAI SC. 1999. Resistance to Vibrio alginolyticus in juvenile rockfish (Sebastes schlegeli) fed diets containing different doses of aloe. Aquaculture 180:13-21.

LOGAMBAL SM AND MichaEL RD. 2001. Azadirachtin - an immunostimulant for Oreochromis mossambicus (Peters). J Aquac Trop 16(4):339-347.

Millezi AF, CARdoso MG, Alves E ANd Picolli RH. 2013. Reduction of Aeromonas hidrophyla biofilm on stainless stell surface by essential oils. Braz J Microbiol 44: 73-80.

Nielsen ME, Høi L, Schmidt AS, QIAN D, Shimada T, SHEN JY AND LARSEN JL. 2001. Is Aeromonas hydrophila the dominant motile Aeromonas species that causes disease outbreaks in aquaculture production in the Zhejiang Province of China? Dis Aquat Organ 46: 23-29.

NinOMIYA M, HATTA H, FUJIKI M, KIM M AND YAMAMOTO TR. 1995. Enhancement of chemotactic activity of yellowtail (Seriola quinqueradiata) leucocytes by oral administration of Quillaja saponin. Fish Shellfish Immun 5: 325-327.

PARK HM, Kim J, Chang KS, Kim BS, YANG YJ, Kim GH, SHIN SC AND PARK IL. 2011. Larvicidal activity of myrtaceae essential oils and their components against Aedes aegypti, acute toxicity on Daphnia magna, and aqueous residue. J Med Entomol 48: 405-410. 
Pascual ME, Slowing K, Carretero E, SÁnches MD and VILLAR A. 2001. Lippia: traditional uses, chemistry and pharmacology: a review. J Ethnopharmacol 76: 201-214.

PICKERING AD AND PotTINGER TG. 1989. Stress responses and disease resistance in salmonid fish: effects of chronic elevation of plasma cortisol. Fish Physiol Biochem 7: 253-258.

QUINN PJ. 1994. Aeromonas, Plesiomonas and Vibrio species. In: Quinn PJ, Carter ME, Markey BK, Carter GR (Eds), Clinical Veterinary Microbiology. Wolfe Publishing, London, UK, p. 243-253.

Rigos G AND TROISI GM. 2005. Antibacterial agents in Mediterranean finfish farming: A sinopsis of drug pharmacokinetics in important euryhaline fish species and possible environmental implications. Rev Fish Biol Fisher 15: 53-73.

Ríos JL AND RECIO MC. 2005. Medicinal plants and antimicrobial activity. J Ethnopharmacol 100: 80-84.
SChMidt AS, BruUn MS, DAlsgaArd I, Pedersen K AND LARSEN JL. 2000. Occurrence of antimicrobial resistance in fish-pathogenic and environmental bacteria associated with four Danish rainbow trout farms. Appl Environ Microbiol 66: 4908-4915.

Smith-PALMER A, STEWART J AND Fyfe L. 2004. Influence of subinhibitory concentrations of plant essential oils on the production of enterotoxins A and B and $\alpha$-toxin by Staphylococcus aureus. J Med Microbiol 53: 1023-1027.

WEDEMEYER GA AND MCLEAY DJ. 1981. Methods for determining the tolerance of fishes to environmental stressors. In: Pickering AD (Ed), Stress and fish. London: Academic Press, pp. 247-275.

Yu HB, Zhang YL, Lau YL, Yao F, Vilches S, Merino S, TOMAS JM, HOWARD SP AND LEUNG KY. 2005. Identification and characterization of putative virulence genes and gene clusters in Aeromonas hydrophila PPD134/91. Appl Environ Microbiol 71(8): 4469-4477. 